\title{
A Novel Validated Analytical Method Development for the Binary Mixture of Mebeverine and Chlordiazepoxide in Pharmaceutical Formulation and its Application to Stress Studies
}

\section{Sujana $K^{*}$, Hamuthal MZV, Murthy VSN and Shravani N}

Department of Pharmaceutical Analysis, University College of Pharmaceutical Sciences, Acharya Nagarjuna University, Nagarjuna Nagar, Guntur - 522510, Andhra Pradesh, India

\begin{abstract}
Purpose: A Stability indicating RP-HPLC method for the determination of Mebeverine and Chlordiazepoxide in bulk and pharmaceutical dosage form was developed and validated. Two methods are available for the determination of this combination and it is required to develop the novel method with cost effective, time consuming, with good sensitivity and less retention time and to know the interference of degradation products which can be performed in the routine analysis

Methods: Stability indicating RP-HPLC method with chromatographic conditions include Agilent C18 column (250 $\mathrm{mm} \times 4.6 \mathrm{~mm}$ i.d., $5 \mu$ particle size) and the mobile phase consists of $40: 60 \mathrm{v} / \mathrm{v}$ ratio of Methanol and Tri ethyl amine buffer $\mathrm{pH} 7.0$ with OPA at a flow rate of $1.0 \mathrm{ml} / \mathrm{min}$ at a ambient temperature and the injection volume was $20 \mu \mathrm{L}$. Results: Quantification was achieved at $262 \mathrm{~nm}$ wavelength using UV detector and the retention times of Mebeverine and Chlordiazepoxide were found to be 3.40 and $7.45 \mathrm{mins}$. The developed method shows linearity in the range $27-$ $216 \mu \mathrm{g} / \mathrm{mL}$ for Mebeverine and 1.8-7.4 $\mu \mathrm{g} / \mathrm{mL}$ for Chlordiazepoxide. The LOD and LOQ values for Mebeverine were $2.2 \mu \mathrm{g} / \mathrm{mL}$ and $6.5 \mu \mathrm{g} / \mathrm{mL}$, for Chlordiazepoxide $0.01 \mu \mathrm{g} / \mathrm{ml}$ and $0.03 \mu \mathrm{g} / \mathrm{ml}$ respectively. The regression coefficient for both drugs was found to be 0.999 . The mean recoveries ranged from $99.99-100.004 \%$ and $99.97-100.01 \%$ for Chlordiazepoxide and Mebeverine respectively. The stability study results show that the method for the determination of both the drugs was stable. The percentage degradation for Mebeverine and Chlordiazepoxide were within the limit that is less than 30 .

Conclusion: Both drugs were eluted with less retention times. Stability was performed which shows that the proposed method was stable. Degradation products were not interfered with the pure drugs of Mebeverine and Chlordiazepoxide. By the stress study the degradation pathways are studied. Hence the developed method was considered as the stability indicating method. The proposed method was performed based on the ICH guidelines.
\end{abstract}

Keywords: RP-HPLC; Mebeverine; Chlordiazepoxide; Forced degradation study; Methanol; Tri ethyl amine; ortho phosphoric acid

\section{Introduction}

Mebeverine is chemically Benzoic acid, 3, 4-dimethoxy-, 4-[ethyl [2-(4-methoxyphenyl)-1-methylethyl] amino] butyl ester, with molecular formula $\mathrm{C}_{25} \mathrm{H}_{35} \mathrm{NO}_{5}$. It is pale yellow crystalline powder which is freely soluble in water and methanol. Mebeverine is an antimuscarinic and belongs to a group of compounds called musculotropic antispasmodics. These compounds act directly on the gut muscles at the cellular level to relax them which relieves muscle spasm pains of gut. It is used for the treatment of irritable bowel syndrome as well as other conditions including chronic irritable colon, spastic constipation and mucous colitis.

Chlordiazepoxide $\mathrm{HCl}$ is 7-chloro-2-(methyl amino)-5-phenyl$3 \mathrm{H}-1$, 4-benzodiazepine 4-oxide hydrochloride. Its molecular formula is $\mathrm{C}_{16} \mathrm{H}_{14} \mathrm{ClN}_{3} \mathrm{O}$. HCl. It is white or slightly yellow solid crystalline in nature and completely soluble in water, may be soluble or sparingly soluble in alcohol and practically insoluble in chloroform. Mechanism of action includes binding of the drug to stereo specific benzodiazepine binding sites on GABA receptors at several sites within the central nervous system which results in an increased binding of the inhibitory neurotransmitter GABA to the GABA (A) receptor. Hence benzodiazepines enhance GABA mediated chloride influx which results in membrane hyperpolarisation. The neuro inhibitory effect results in sedative, hypnotic, anxiolytic and muscle relaxant properties. By the muscle relaxant property it is used for treatment of irritable bowel syndrome along with Mebeverine.
From the literature survey it was concluded that only few RPHPLC methods [1], have been reported for the determination of Mebeverine and Chlordiazepoxide in combination. Certain methods for the estimation of Mebeverine and Chlordiazepoxide in combined dosage forms include UV spectrophotometric method [2]. Mebeverine has been determined either alone or in other drug combination by various methods includes RP-HPLC [3-8] and Chlordiazepoxide also determined either alone or in other drug combination by various methods includes RP-HPLC [9-14], simultaneous spectrophotometric method.

Only few methods for the simultaneous estimation of Mebeverine and Chlordiazepoxide have been reported. So, the present work was done with aim to develop a new stability indicating RP-HPLC method and validated according to ICH guidelines.

*Corresponding author: Sujana K, Department of Pharmaceutical Analysis, University College of Pharmaceutical Sciences, Acharya Nagarjuna University Nagarjuna Nagar, Guntur-522510, Andhra Pradesh, India, Tel: 09492842585 E-mail: sujana_36@yahoo.co.in

Received November 13, 2014; Accepted December 15, 2014; Published December 19, 2014

Citation: Sujana K, Hamuthal MZV, Murthy VSN, Shravani N (2015)A Nove Validated Analytical Method Development for the Binary Mixture of Mebeverine and Chlordiazepoxide in Pharmaceutical Formulation and its Application to Stress Studies. Pharm Anal Acta 6: 324. doi:10.4172/2153-2435.1000324

Copyright: @ 2015 Sujana K, et al. This is an open-access article distributed unde the terms of the Creative Commons Attribution License, which permits unrestricted use, distribution, and reproduction in any medium, provided the original author and source are credited. 
Citation: Sujana K, Hamuthal MZV, Murthy VSN, Shravani N (2015)A Novel Validated Analytical Method Development for the Binary Mixture of Mebeverine and Chlordiazepoxide in Pharmaceutical Formulation and its Application to Stress Studies. Pharm Anal Acta 6: 324. doi:10.4172/2153-2435.1000324

Page 2 of 6

\section{Methodology}

\section{Materials}

Instrumentation: The separation was carried out on Waters 2695 HPLC system using Agilent C18 column $(250 \times 4.6 \mathrm{~mm} ; 5 \mu \mathrm{m})$, isocratic HPLC pump and UV detector. Empower software was used for the data acquisition and quantification of peaks of Mebeverine and Chlordiazepoxide. Denver instrument- weighing balance, ultrasonicator bath model-UCA 701 was used.

Chemicals and reagents: Mebeverine and Chlordiazepoxide pure drug and capsules, HPLC grade Methanol (Merck), Acetonitrile of HPLC grade, ortho phosphoric acid, Triethylamine and HPLC grade analytical water were used.

Chromatographic conditions: The chromatographic column used was Agilent C18 $250 \mathrm{~mm}$ x $4.6 \mathrm{~mm}, 5 \mu$ particle size. The mobile phase consists of 40:60 ratio of Methanol and Tri ethyl amine buffer $\mathrm{pH} 7.0$ (v/v) adjusted using ortho phosphoric acid. Flow rate was $1.0 \mathrm{~mL} / \mathrm{min}$ at an ambient temperature and the chromatograms were monitored at a detector wavelength of $262 \mathrm{~nm}$ using UV-Detector. The injection volume was $20 \mu \mathrm{L}$.

\section{Preparation of standard solutions}

Solution A: Mebeverine: Weigh accurately about $135 \mathrm{mg}$ of Mebeverine pure drug into a $100 \mathrm{~mL}$ volumetric flask. $70 \mathrm{~mL}$ of mobile phase was added then sonicate to dissolve and dilute to volume with mobile phase

Solution B: Chlordiazepoxide: Weigh accurately about $5 \mathrm{mg}$ of Chlordiazepoxide pure drug into a $100 \mathrm{~mL}$ volumetric flask.70 mL of mobile phase was added then sonicate to dissolve and dilute to volume with mobile phase. Further dilute each $5 \mathrm{~mL}$ of Solution-A and Solution-B to $50 \mathrm{~mL}$ with the mobile phase to get the concentrations of $135 \mu \mathrm{g} / \mathrm{ml}$ and $5 \mu \mathrm{g} / \mathrm{ml}$, from which different concentrations are prepared according to the linearity range.

Assay of sample solution: 10 capsules were weighed and reweighed powder and tablets individually from capsules. Equivalent weight of 5 capsules of sample was taken into a $250 \mathrm{~mL}$ volumetric flask. Add $200 \mathrm{~mL}$ of mobile phase, sonicate to dissolve and dilute to volume with mobile phase. Filter through $0.45 \mu$ Nylon syringe filter. Further dilute $5 \mathrm{~mL}$ to $100 \mathrm{~mL}$ with the mobile phase to get the concentrations of 135 $\mu \mathrm{g} / \mathrm{ml}$ of Mebeverine and $5 \mu \mathrm{g} / \mathrm{ml}$ of Chlordiazepoxide respectively. Both Standard and sample solutions were injected into injection system and chromatograms were recorded.

\section{Method Validation}

The validation of RP-HPLC method for the determination of Mebeverine and Chlordiazepoxide as per the protocol and to demonstrate that the method is appropriate for its intended use was studied for the following parameters. All the validation parameters were carried out according to ICH guide lines.

\section{Specificity}

Specificity of an analytical method is ability to measure specifically the analyte of interest without interference from blank and known impurities. For this purpose blank chromatogram, standard chromatogram and sample chromatogram were recorded, at the retention times of drugs which confirm the response of drugs was specific. The specificity parameters were given.

\section{Accuracy}

The accuracy parameter was carried out by the standard addition method at $80 \%, 100 \%$ and $120 \%$ levels of linearity and the recoveries obtained were given.

\section{Precision}

The precision were checked by repeatedly injecting $(n=6)$ solutions of $135 \mu \mathrm{g} / \mathrm{mL}$ Mebeverine and $5 \mu \mathrm{g} / \mathrm{mL}$ Chlordiazepoxide in combination.

\section{Intermediate precision (Reproducibility)}

The precision study includes intraday and inter day of the proposed methods were determined by the corresponding responses three times on the same day and on three different days over a period of one week for three different concentration of $135 \mu \mathrm{g} / \mathrm{mL}$ Mebeverine and $5 \mu \mathrm{g} /$ mL Chlordiazepoxide

The \% RSD values were low for Mebeverine and Chlordiazepoxide which reveal that the proposed method was precise.

\section{Limit of Detection (LOD) and Limit of Quantification (LOQ)}

The limit of detection (LOD) limit of quantification (LOQ) of the drug carry was calculated from the linearity curve using the following equation as per international conference harmonization ( $\mathrm{ICH}$ ) guidelines.

$$
\begin{aligned}
& \mathrm{LOD}=3.3 \times \sigma / \mathrm{S} \\
& \mathrm{LOQ}=10 \mathrm{X} \sigma / \mathrm{S} \\
& \sigma=\text { standard deviation } \\
& \mathrm{S}=\text { slope }
\end{aligned}
$$

\section{Linearity and Range}

Linearity of an analytical method is its ability to elicit the test results that are either directly or by a defined mathematical transformation which should be proportional to the analyte concentration in sample within a given range. Linear correlation was obtained between peak area vs. concentration of Mebeverine and Chlordiazepoxide were in the range of $27-216 \mu \mathrm{g} / \mathrm{mL}$ and $1.8-7.4 \mu \mathrm{g} / \mathrm{mL}$.The linearity of the calibration curve was validated by the high value of correlation coefficient of regression equation and the results were given.

The analytical method shows the range which is the interval between the upper and lower levels of analyte (including these levels) that have been demonstrated with precision, accuracy and linearity.

\section{Robustness and Ruggedness}

Robustness of the method was determined by carrying out the analysis at two different $\mathrm{pH}$ of mobile phase (i.e. $7.0 \pm 0.5$ ) and three different flow rates (i.e. $1 \pm 0.2 \mathrm{~mL} / \mathrm{min}$ )

The high \% RSD values of robustness and for Mebeverine and Chlordiazepoxide with change in flow rate indicates that the method is not robust for change in flow rate. The low \% RSD values of robustness for Mebeverine and Chlordiazepoxide with change in $\mathrm{P}^{\mathrm{H}}$ and Flow rate reveal that the proposed experimental method was robust.

Ruggedness of the method was determined by carrying out the analysis by two different analysts and the respective peak areas were noted. The result was indicated by \% RSD (Figures 1-5). 
Citation: Sujana K, Hamuthal MZV, Murthy VSN, Shravani N (2015)A Novel Validated Analytical Method Development for the Binary Mixture of Mebeverine and Chlordiazepoxide in Pharmaceutical Formulation and its Application to Stress Studies. Pharm Anal Acta 6: 324. doi:10.4172/2153-2435.1000324

Page 3 of 6

\section{Stability Study}

$135 \mu \mathrm{g} / \mathrm{ml}$ Mebeverine and $5 \mu \mathrm{g} / \mathrm{ml}$ Chlordiazepoxide was prepared and the stability study was carried out for the standard drug solution at $0 \mathrm{hrs}, 6 \mathrm{hrs}, 12 \mathrm{hrs}, 18 \mathrm{hrs}$ and $24 \mathrm{hrs}$. The results reveal that the sample solutions are stable and accurate without interference.

\section{Forced degradation study}

Forced degradation studies are also known as testing of stress, decomposition stress studies, forced decomposition studies, etc. Degradation conditions include hydrolytic conditions, oxidative conditions, photolytic conditions, thermal conditions and humidity. The results of degradation study were given in the table.

\section{Acid degradation}

Powder equivalent to $135 \mathrm{mg}$ of Mebeverine and $5 \mathrm{mg}$ of Chlordiazepoxide were weighed accurately and transferred into two separate $100 \mathrm{~mL}$ round bottomed flasks, made up the mark with the solvent. Then $5 \mathrm{~mL}$ was transferred into $50 \mathrm{~mL}$ volumetric flask and diluted with the same solvent. From this $1 \mathrm{ml}$ was transfer into $10 \mathrm{~mL}$ volumetric flask and $1 \mathrm{~mL}$ of $0.1 \mathrm{~N} \mathrm{HCl}$ was added and reflux for $30 \mathrm{~min}$ at $60^{\circ} \mathrm{C}$.Cooled to room temperature and neutralized with $1 \mathrm{~mL}$ of $0.1 \mathrm{~N}$ $\mathrm{NaOH}$ and made up the volume with HPLC grade solvent.

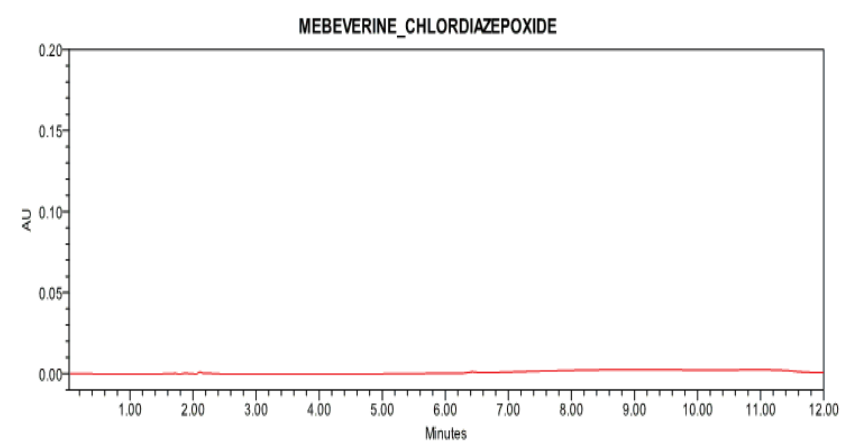

Figure 1: Blank Chromatogram of Mebeverine and Chlordiazepoxide at 262nm

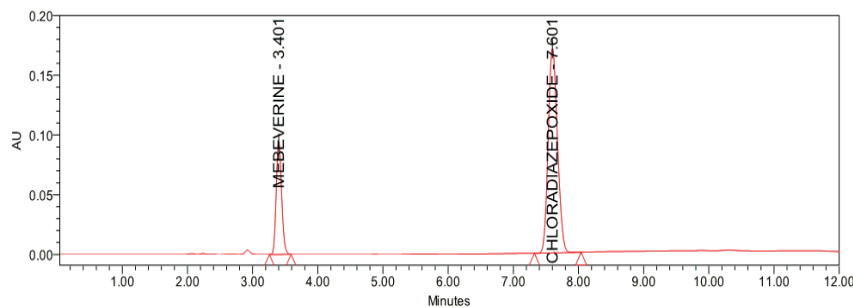

Figure 2: Chromatogram of Mebeverine and Chlordiazepoxide at $262 \mathrm{~nm}$ in bulk analysis

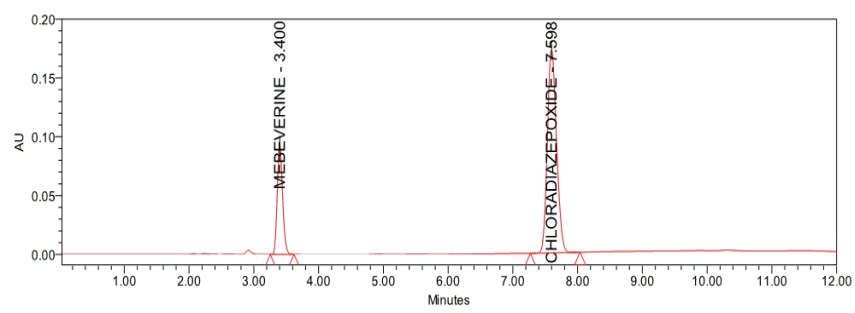

Figure 3: Chromatogram of Mebeverine and Chlordiazepoxide at $262 \mathrm{~nm}$ in formulation analysis

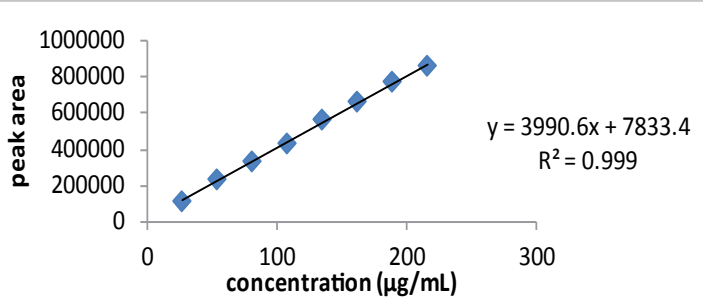

Figure 4: Linearity of Mebeverine: Calibration curve for Mebeverine at $262 \mathrm{~nm}$

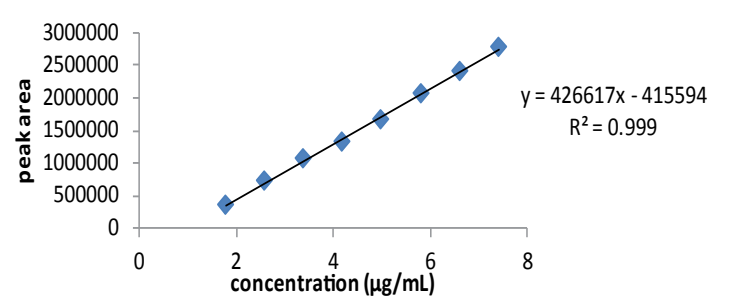

Figure 5: Linearity of Chlordiazepoxide : Calibration curve of Chlordiazepoxide at $262 \mathrm{~nm}$

\section{Base degradation}

$1 \mathrm{ml}(135 \mu \mathrm{g} / \mathrm{mL}$ and $5 \mu \mathrm{g} / \mathrm{mL})$ of above solution of Mebeverine and Chlordiazepoxide were transferred into $10 \mathrm{~mL}$ volumetric flask and 1 $\mathrm{ml}$ of $0.1 \mathrm{~N} \mathrm{NaOH}$ was added and reflux for $30 \mathrm{~min}$ at $60^{\circ} \mathrm{C}$.Cooled to room temperature and neutralized with $1 \mathrm{~mL}$ of $0.1 \mathrm{~N} \mathrm{HCl}$ and made up the volume with HPLC grade water solvent.

\section{Peroxide}

$1 \mathrm{ml}(135 \mu \mathrm{g} / \mathrm{mL}$ and $5 \mu \mathrm{g} / \mathrm{mL})$ of above solution of Mebeverine and Chlordiazepoxide were transferred to $10 \mathrm{~mL}$ volumetric flask and $1 \mathrm{~mL}$ of $3 \% \mathrm{v} / \mathrm{v}$ of $\mathrm{H}_{2} \mathrm{O}_{2}$ was added and reflux for $30 \mathrm{~min}$ at $60^{\circ} \mathrm{C}$.Cooled to room temperature and made up the volume with HPLC grade solvent.

\section{Thermal degradation}

Weigh accurately 20 capsules and crush the tablets in it into fine powder and transfer capsule powder and tablet powder into two separate petridishes. Heat the samples in oven for about $6 \mathrm{hrs}$ at $105^{\circ} \mathrm{C}$. From this weigh accurately $100 \mathrm{mg}$ of powdered sample into a $100 \mathrm{ml}$ volumetric flask dissolve and dilute to volume with HPLC grade water. Transfer $1 \mathrm{ml}$ of above stock solution to $10 \mathrm{ml}$ volumetric flask and filter the solution using $0.45 \mu$ Nylon filter.

\section{Photolytic degradation}

Photolytic degradation study was carried out by exposing the accurately weighed tablet and capsule powder to UV light in a photolytic chamber at 2600 lux for $24 \mathrm{hr}$, after $24 \mathrm{hrs}$ weigh accurately $1522 \mathrm{mg}$ of powdered sample into a $100 \mathrm{ml}$ volumetric flask. Dissolve and dilute to volume with HPLC grade water .Transfer $1 \mathrm{ml}$ of above stock solution to $10 \mathrm{ml}$ volumetric flask and filter the solution using $0.45 \mu$ Nylon filter. Using the peak purity test, the purity of the drugs peaks were checked at every stage of above-mentioned studies (Tables 1-11).

\section{Discussion}

The present study was carried out in order to develop a sensitive and accurate stability indicating RP-HPLC method for the simultaneous analysis of Mebeverine and Chlordiazepoxide in pharmaceutical dosage forms. The mobile phase consists of 40:60 ratio of methanol and Tri ethyl amine buffer $\mathrm{pH} 7.0(\mathrm{v} / \mathrm{v})$ on Agilent C18 
Citation: Sujana K, Hamuthal MZV, Murthy VSN, Shravani N (2015)A Novel Validated Analytical Method Development for the Binary Mixture of Mebeverine and Chlordiazepoxide in Pharmaceutical Formulation and its Application to Stress Studies. Pharm Anal Acta 6: 324. doi:10.4172/2153-2435.1000324

Page 4 of 6

\begin{tabular}{|c|c|c|c|c|c|c|c|c|c|}
\hline Drug & Avgstd area & Avg sample area & Avgwt of tab. (mg) & Stdwt (mg) & Sample wt(mg) & Label amount (mg) & Std purity & Amount found (mg) & \% assay \\
\hline Chlordiazepoxide & 1677568 & 1698788 & 327.5 & 5 & 5.05 & 5 & 100.3 & 5.05 & 100.3 \\
\hline Mebeverine & 5436 & 541787 & 327.5 & 136.5 & 136.5 & 135 & 100.1 & 136.24 & 100.1 \\
\hline
\end{tabular}

Table 1: Results of assay for formulation

\begin{tabular}{|c|c|c|c|c|}
\hline S.No & Drug & Retention time(min) & Plate count & Tailing factor \\
\hline 1 & Mebeverine & 3.400 & 7676 & 1.146 \\
\hline 2 & Chlordiazepoxide & 7.598 & 13186 & 1.14 \\
\hline Acceptance criteria & & & $>2000$ & $<.84$ \\
\hline
\end{tabular}

Table 2: System suitability parameters for Mebeverine and Chlordiazepoxide

\begin{tabular}{|c|c|c|c|c|c|c|c|}
\hline S. NO & $\%$ Level of Standard & Conc. Of working std. Added $(\mu \mathrm{g} / \mathrm{ml})$ & Peak area & Amount recovered & $\%$ recovery & Mean recovery & $\%$ R.S.D \\
\hline \multirow{3}{*}{1} & \multirow{3}{*}{80} & \multirow{3}{*}{$40.5+67.5$} & 427826 & \multirow{3}{*}{108.006} & \multirow{3}{*}{100.000} & \multirow{9}{*}{99.993} & \multirow{9}{*}{0.023} \\
\hline & & & 427759 & & & & \\
\hline & & & 427965 & & & & \\
\hline \multirow{3}{*}{2} & \multirow{3}{*}{100} & \multirow{3}{*}{$67.5+67.5$} & 556811 & \multirow{3}{*}{134.94} & \multirow{3}{*}{99.97} & & \\
\hline & & & 556620 & & & & \\
\hline & & & 556526 & & & & \\
\hline \multirow{3}{*}{3} & \multirow{3}{*}{150} & \multirow{3}{*}{$94.5+67.5$} & 662275 & \multirow{3}{*}{162.026} & \multirow{3}{*}{100.01} & & \\
\hline & & & 662548 & & & & \\
\hline & & & 662324 & & & & \\
\hline
\end{tabular}

Table 3: Accuracy results of Mebeverine by RP-HPLC method

\begin{tabular}{|c|c|c|c|c|c|c|c|}
\hline S. NO & $\%$ Level of Standard & Conc. Of working std. Added $(\mu \mathrm{g} / \mathrm{ml})$ & Peak area & Amount recovered & $\%$ recovery & Mean recovery & $\%$ R.S.D \\
\hline \multirow{3}{*}{1} & \multirow{3}{*}{80} & \multirow{3}{*}{$1.35+2.25$} & 1330215 & \multirow{3}{*}{3.6001} & \multirow{3}{*}{100.004} & \multirow{9}{*}{99.994} & \multirow{9}{*}{0.0072} \\
\hline & & & 1330152 & & & & \\
\hline & & & 1330457 & & & & \\
\hline \multirow{3}{*}{2} & \multirow{3}{*}{100} & \multirow{3}{*}{$2.25+2.25$} & 1739493 & \multirow{3}{*}{4.49} & \multirow{3}{*}{99.99} & & \\
\hline & & & 1739265 & & & & \\
\hline & & & 1739350 & & & & \\
\hline \multirow{3}{*}{3} & \multirow{3}{*}{150} & \multirow{3}{*}{$3.15+2.25$} & 2065927 & \multirow{3}{*}{5.39} & \multirow{3}{*}{99.995} & & \\
\hline & & & 2065795 & & & & \\
\hline & & & 2065802 & & & & \\
\hline
\end{tabular}

Table 4: Accuracy results of Chlordiazepoxide by RP-HPLC method

\begin{tabular}{|c|c|c|c|c|}
\hline \multirow{2}{*}{ S.No } & \multicolumn{2}{|c|}{ Chlordiazepoxide } & \multicolumn{2}{|c|}{ Mebeverine } \\
\hline & Conc. $(\mu \mathrm{g} / \mathrm{ml})$ & Peak area & Conc. $(\mu \mathrm{g} / \mathrm{ml})$ & Peak area \\
\hline 1 & 0.9 & 357120 & 27 & 113631 \\
\hline 2 & 1.8 & 719553 & 54 & 229332 \\
\hline 3 & 2.7 & 1058676 & 81 & 324241 \\
\hline 4 & 3.6 & 1330215 & 108 & 427826 \\
\hline 5 & 4.5 & 1739493 & 135 & 556811 \\
\hline 6 & 5.4 & 2065927 & 162 & 662275 \\
\hline 7 & 6.3 & 2404976 & 189 & 771203 \\
\hline 8 & 7.2 & 2768594 & 216 & 856249 \\
\hline \multicolumn{2}{|c|}{ Regression equation } & $y=381324 x+10048$ & \multicolumn{2}{|c|}{$y=4010 x+4873.7$} \\
\hline Slope & \multicolumn{2}{|c|}{381324} & \multicolumn{2}{|c|}{4010} \\
\hline Intercept & \multicolumn{2}{|c|}{10048} & \multicolumn{2}{|c|}{4873.7} \\
\hline $\mathrm{R}^{2}$ & \multicolumn{2}{|c|}{0.999} & \multicolumn{2}{|c|}{0.999} \\
\hline
\end{tabular}

Table 5: Linearity for Mebeverine and Chlordiazepoxide at $262 \mathrm{~nm}$

\begin{tabular}{|c|c|c|c|c|c|c|c|}
\hline \multirow{2}{*}{ S.NO } & \multirow{2}{*}{ TYPE } & \multicolumn{3}{|c|}{ Chlordiazepoxide } & \multicolumn{2}{|c|}{ Mebeverine } \\
\cline { 2 - 6 } & & Mean area & Std. deviation & $\%$ RSD & Mean area & Std. deviation & $\%$ RSD \\
\hline 1 & System precision & 1677620 & 4429.59 & 0.264 & 543735 \\
\hline 2 & Method precision & 1673928 & 5814.12 & 0.347 & 541422 & 2780 \\
\hline 3 & Intermediate precision & 1669300.6 & 8412.36 & 0.503 & 537365.8 & 2534.03 \\
\hline
\end{tabular}

Table 6: Precision studies by RP-HPLC method 
Citation: Sujana K, Hamuthal MZV, Murthy VSN, Shravani N (2015)A Novel Validated Analytical Method Development for the Binary Mixture of Mebeverine and Chlordiazepoxide in Pharmaceutical Formulation and its Application to Stress Studies. Pharm Anal Acta 6: 324. doi:10.4172/2153-2435.1000324

Page 5 of 6

\begin{tabular}{|c|c|c|c|c|}
\hline s.no & Parameter & Mebeverine & Chlordiazepoxide & Limit \\
\hline 1 & $\%$ RSD & 0.348 & 0.264 & NMR $2.0 \%$ \\
\hline
\end{tabular}

Table 7: Results of Ruggedness study by RP-HPLC

\begin{tabular}{|c|c|c|c|c|c|c|c|c|}
\hline \multirow{2}{*}{ Variations } & \multicolumn{4}{|c|}{ Chlordiazepoxide } & \multicolumn{4}{|c|}{ Mebeverine } \\
\hline & Retention time & Peak area & Plate count & $\%$ RSD & Retention time & Peak area & Plate count & $\%$ RSD \\
\hline $\mathrm{P}^{\mathrm{H}}=6.5$ & 7.165 & 1757140 & 17902 & 0.32 & 3.298 & 561797 & 8790 & 0.1 \\
\hline $\mathrm{P}^{\mathrm{H}}=7.5$ & 9.24 & 2185148 & 16317 & 0.11 & 4.23 & 697128 & 9395 & 0.11 \\
\hline Flow rate $1.1 \mathrm{~mL} / \mathrm{min}$ & 6.44 & 1446089 & 11260 & 0.21 & 2.84 & 465104 & 6662 & 0.26 \\
\hline Flow rate $0.9 \mathrm{ml} / \mathrm{min}$ & 9.24 & 218514 & 16317 & 0.23 & 4.23 & 697128 & 9395 & 0.2 \\
\hline
\end{tabular}

Table 8: Results of Robustness study by RP-HPLC

\begin{tabular}{|c|c|c|c|}
\hline \multirow{2}{*}{ Parameter } & \multicolumn{2}{|c|}{ Chlordiazepoxide } & \multicolumn{2}{c}{ Mebeverine } \\
\cline { 2 - 4 } & $\mu \mathrm{g} / \mathrm{mL}$ & Area & $\mu \mathrm{g} / \mathrm{mL}$ \\
\hline LOD & 0.01 & 3968 & 2.2 \\
\hline LOQ & 0.03 & 11904 & 9258 \\
\hline
\end{tabular}

Table 9: Sensitivity parameters (LOD \& LOQ) by RP-HPLC

\begin{tabular}{|c|c|c|c|c|c|c|c|c|c|}
\hline \multirow{2}{*}{$\begin{array}{l}\text { Time period } \\
\text { (hours) }\end{array}$} & \multicolumn{4}{|c|}{ Chlordiazepoxide } & \multicolumn{4}{|c|}{ Mebeverine } & \multirow{2}{*}{ Resolution } \\
\hline & Retention time & Peak area & Tailing factor & Plate count & Retention time & Peak area & Tailing factor & Plate count & \\
\hline 6 & 7.595 & 1672263 & 1.16 & 12575 & 3.4 & 531947 & 1.12 & 7525 & 19.30 \\
\hline 12 & 7.598 & 1662418 & 1.16 & 11832 & 3.399 & 534078 & 1.13 & 7203 & 18.82 \\
\hline 18 & 7.606 & 1677732 & 113 & 13054 & 3.402 & 544222 & 1.14 & 7587 & 19.67 \\
\hline 24 & 7.604 & 1674413 & 1.13 & 13500 & 3.402 & 541523 & 1.14 & 7881 & 19.98 \\
\hline
\end{tabular}

Table 10: Results of stability study for Mebeverine and Chlordiazepoxide

\begin{tabular}{|c|c|c|c|c|c|c|c|}
\hline \multirow{2}{*}{ Degradation } & \multirow{2}{*}{ Sample } & \multicolumn{3}{|c|}{ Chlordiazepoxide } & \multicolumn{3}{|c|}{ Mebeverine } \\
\hline & & Mean area & $\%$ label claim & $\%$ degradation & Mean area & $\%$ label claim & $\%$ degradation \\
\hline Control & 1652.8 & 1693405 & 100 & 0 & 542695 & 100.3 & -0.3 \\
\hline Acid & 1849.2 & 1501905 & 79.3 & 20.7 & 483645 & 79.9 & 20.4 \\
\hline Alkali & 1542.7 & 1158534 & 79.3 & 26.7 & 372786 & 73.8 & 26.5 \\
\hline Peroxide & 1582.9 & 1167374 & 72 & 28 & 374187 & 72.2 & 28.1 \\
\hline Thermal & 1510.9 & 1157940 & 74.8 & 25.2 & 373570 & 75.5 & 24.8 \\
\hline Photo & 1522.3 & 1139725 & 73.1 & 26.9 & 366961 & 73.6 & 26.7 \\
\hline
\end{tabular}

Table 11: Results of degradation study for Mebeverine and Chlordiazepoxide

column $(240 \times 4.6 \mathrm{~mm}, 5 \mu \mathrm{m})$ analytical column was used to effect the separation of drugs and reference standard under isocratic conditions and to produce good resolution and free from tailing and fronting. Mebeverine and Chlordiazepoxide retention times were obtained at $3.40 \mathrm{~min}$ and $7.59 \mathrm{~min}$. From the specificity chromatograms it was clarified that the peaks of pure drug and sample were not showing any interferences by comparing the blank chromatogram. In order to test the linearity of the method, dilutions of the working standard solutions of drugs were prepared in the range of $27-216 \mu \mathrm{g} / \mathrm{mL}$ for Mebeverine and 1.8-7.4 $\mu \mathrm{g} / \mathrm{mL}$ for Chlordiazepoxide. A good linear relationship $\left(r^{2}=0.99\right)$ was observed between the concentrations of Mebeverine and Chlordiazepoxide and the corresponding peak areas. The method was duly validated by evaluation of the required parameters as per ICH guidelines. The system suitability parameters were within the limits as shown. The proposed method was found to be precise as the \%RSD values for intra-day and inter-day were found to be less than $2 \%$.The recoveries of Mebeverine and Chlordiazepoxide obtained from the preanalyzed samples containing known amounts of added drug were shown which were within the acceptable range indicating the high accuracy of the proposed method. Robustness of the method was found out by testing the effect of small deliberate changes in the chromatographic conditions and the areas of corresponding peaks. The main factors selected in this method were the flow rate $( \pm 0.2)$ and the detection $\mathrm{P}^{\mathrm{H}}(0.5)$ and the results were recorded. LOD and LOQ of the method were calculated basing on standard deviation of the response and the slope(s) of the calibration curve and the values for the proposed HPLC method were within the limits. The drug content in the formulation was quantified using the proposed method of analysis and the mean amount of Mebeverine and Chlordiazepoxide obtained in dosage form were in the range of $98 \%-102 \%$.Stability study results and degradation results were recorded. The results shows that the drugs were degraded more by peroxide treatment and also reveals the degradation pathways by treating the drug with acid, alkali, peroxide, heat and light. All these results reveal that the method was stable without any interference, accurate, precise, less time consuming and economical.

\section{Conclusion}

A RP HPLC method was developed and applied stress studies which explains that the method was stable, simple, accurate and sensitive for the determination of Mebeverine and Chlordiazepoxide in combined dosage form.

\section{References}

1. Haggag RS, Shaalan RA, Belal TS (2010) Validated HPLC determination of the two fixed dose combinations (chlordiazepoxide hydrochloride and mebeverine hydrochloride; carvedilol and hydrochlorothiazide) in their tablets. See comment in PubMed Commons below J AOAC Int 93: 1192-1200.

2. (2007) Indian pharmacopoeia Vol. III, Government of India, Ministry of Health and family Welfare, Controller of publications, Delhi, 2037. 
Citation: Sujana K, Hamuthal MZV, Murthy VSN, Shravani N (2015)A Novel Validated Analytical Method Development for the Binary Mixture of Mebeverine and Chlordiazepoxide in Pharmaceutical Formulation and its Application to Stress Studies. Pharm Anal Acta 6: 324. doi:10.4172/2153-2435.1000324

3. Radwan MA, Abdine $\mathrm{HH}$, Aboul-Enein $\mathrm{HY}$ (2006) A validated chiral HPLC method for the determination of mebeverine $\mathrm{HCl}$ enantiomers in pharmaceutical dosage forms and spiked rat plasma. See comment in PubMed Commons below Biomed Chromatogr 20: 211-216.

4. Mohamed I Walash, Mohie M KhSharaf El-din, Nahed M El-enany, Manal I Eid, Shereen M Shalan (2012) Simultaneous determination of sulpiride and mebeverine by HPLC method using fluorescence detection: application to rea human plasma. Chem Cent J 6: 13.

5. E. Souri1, Aghdami N, Adib N (2014) A stability indicating HPLC method for determination of mebeverine in the presence of its degradation products and kinetic study of its degradation in oxidative condition. Reseacrch in pharmaceutical sciences 9: 199-206.

6. Doki A, Kamarapu SK (2013) Method development and validation of RP-HPLC method for simultaneous estimation of clidinium bromide, chlordiazepoxide and dicyclomine hydrochloride in bulk and combined tablet dosage forms. International journal of pharmacy and biological sciences 3: 152-161.

7. Ashour S, Kattan N (2013) Simultaneous Determination of Clidinium Bromide and Chlordiazepoxide in Combined Dosage Forms by High-Performance Liquid Chromatography. Journal of pharmaceutics.

8. Hatami M, Farhadi K, Tukmechi A (2012) Fiber-based liquid-phase microextraction of mebeverine enantiomers followed by chiral high-performance liquid chromatography analysis and its application to pharmacokinetics study in rat plasma. See comment in PubMed Commons below Chirality 24: 634-639.

9. Patel SK, Patel NJ (2009) Simultaneous RP-HPLC Estimation of Trifluoperazine Hydrochloride and Chlordiazepoxide in Tablet Dosage Forms. See comment in PubMed Commons below Indian J Pharm Sci 71: 545-547.

10. Arayne MS, Sultana N, Siddiqui FA (2005) A new RP-HPLC method for analysis of mebeverine hydrochloride in raw materials and tablets. See comment in PubMed Commons below Pak J Pharm Sci 18: 11-14.

11. Maheswar KU, Kalyani SG, Rambabu C (2013) Development and validation of a RP-HPLC method for the determination of chlordiazepoxide in formulations. Scholars research library, Der pharma chemica, 5: 288-293.

12. Patel S, Patel NJ (2009) Spectrophotometric and chromatographic simultaneous estimation of amitriptyline hydrochloride and chlordiazepoxide in tablet dosage forms. Indian J Pharm Sci 71: 472-476.

13. SujathaN, Pavani KH (2013) Analytical method development and validation of amitriptyline hydrochloride and chlordiazepoxide in tablet by RP-HPLC. Indian journal of research in pharmacy and biotechnology.

14. Patel DJ, Patel JK, Patel VP (2011) Simultaneous spectrophotometric estimation of mebeverine hydrochloride and chlordiazepoxide in tablet dosage form. 